\title{
THIOCYANATE DEGRADATION BY PURE AND MIXED CULTURES OF MICROORGANISMS
}

\author{
Elaine M. Souza-Fagundes ${ }^{2 *}$; Luiz H. Rosa $^{4}$; Newton C.M. Gomes ${ }^{1,2}$; Mércia H. Santos ${ }^{1}$; Patricia F. Pimentel ${ }^{1}$ \\ ${ }^{1}$ Laboratório de Química de Produtos Naturais, Centro de Pesquisas René Rachou, FIOCRUZ/MG, Belo Horizonte, MG, Brasil; \\ ${ }^{2}$ Setor de Biotecnologia e Tecnologia Química, Fundação Centro Tecnológico de Minas Gerais, Belo Horizonte, MG, Brasil; \\ ${ }^{3}$ Laboratório de Taxonomia e Ecologia Microbiana, Instituto de Microbiologia Prof. Paulo de Góes, Universidade Federal do \\ Rio de Janeiro, Rio de Janeiro, RJ, Brasil; ${ }^{4}$ Departamento de Microbiologia, Instituto de Ciências Biológicas, Universidade \\ Federal de Minas Gerais, Belo Horizonte, MG, Brasil
}

Submitted: November 05, 2002; Returned to authors for corrections: April 07, 2004; Approved: September 27, 2004

\section{SHORT COMMUNICATION}

\begin{abstract}
A mixed culture and a pure bacterial strain (BMV8) were isolated from a bioreactor for thiocyanate treatment. Both cultures removed $5 \mathrm{mM}$ of thiocyanate from the medium in 36 hours. The mixed culture was able to tolerate concentrations up to $60 \mathrm{mM}$. The efficiency of thiocyanate degradation decreased when the cells were immobilized.
\end{abstract}

Key words: biodegradation, cyanate, immobilization; microorganisms, thiocyanate

Cyanide is present in high concentration in effluents and as solid mine tailings. Due to its toxicity, cyanide is converted to thiocyanate by the addition of sulfur at high temperature and alkalinity $(11,20)$. Thiocyanate $\left(\mathrm{SCN}^{-}\right)$is used in a variety of industrial processes, such as photofinishing, herbicide and insecticide production, dyeing, acrylic fiber production, manufacturing of thiourea, metal separation and electroplating, as well as corrosion inhibitor $(3,10)$. The presence of free and metal-complex cyanides in industrial wastewasters is an important environmental problem considering the acute toxicity of these species for living organisms $(5,6)$. The resultant thiocyanate of wastewaters is usually treated by an activated sludge process, where microbial activity degrades this substance as source of nitrogen, sulfur, nitrogen and, energy $(11,16)$. Since biological treatment is limited to a very low concentration of cyanides (6), microbial degradation of thiocyanate has been extensively studied $(5,10)$. The present study reports the results obtained with thiocyanate degradation by mixed and pure cultures of a bacterial strain isolated from a fixed bed bioreactor for cyanide and thiocyanate removal.

Liquid samples were collected from a laboratory scale fixed bed bioreactor used for the study of mining effluent treatment by the company "Mineração Morro Velho" (Nova Lima, MG, Brazil) and cultured in modified minimal salt medium M9 $(2,12)$ plus $5 \mathrm{mM}$ thiocyanate (Merck, Germany) as nitrogen source and $11 \mathrm{mM}$ glucose as carbon source. The MIC values were determined in $250 \mathrm{ml}$ Erlenmeyers flasks containing $25 \mathrm{ml}$ of M9 medium, with increasing thiocyanate concentrations ( 7 to $70 \mathrm{mM}$ ). The incubation was carried out at $30^{\circ} \mathrm{C}$ in rotary shaker at $250 \mathrm{rev} \cdot \mathrm{min}^{-1}$. An $1 \%(\mathrm{v} / \mathrm{v})$ culture, grown for $48 \mathrm{~h}$ in the same medium, was used as inoculum and the growth was evaluated by measuring dry weight. The MIC was defined as the lowest concentration of inhibitor above which no growth was observed. The thiocyanate degradation profile was studied either by culturing the mixed culture and the BMV8 strain immobilized in citric pectin. Citric pectin $(4 \%, \mathrm{w} / \mathrm{w})$ (Citrus Colloids - low methoxy - amide gel) was dissolved in

*Corresponding author. Mailing address: Centro de Pesquisas René Rachou-Fiocruz, Av. Augusto de Lima 1715 , 30190002 Belo Horizonte, MG, Brasil. E-mail: elaine@cpqrr.fiocruz.br 
distilled deionized water and mixed with a magnetic stirrer for 1 hour at room temperature. This solution was then added to the mixed bacterial culture or the BMV8 strain containing $10 \%$ (w/v) dry weight. This final solution (pectin-microorganism) was added to a $0.2 \mathrm{M}$ solution of $\mathrm{BaCl}_{2}$. A spontaneous crosslinking reaction occurred, resulting in spherical beads with an average diameter of about $3 \mathrm{~mm}$, which were stored at $4^{\circ} \mathrm{C}$ for 24 hours. The beads were then washed with distilled deionized water to remove excess $\mathrm{BaCl}_{2}$ (20 g wet weight). In all steps, non-inoculated controls containing M9 medium with thiocyanate and glucose were run. Thiocyanate was determined by the method of Stafford and Callely (13). Glucose was determined by a colorimetric method (15). Ammonia was determined by the assay of Fawcett and Scott (9). Each experiment was run in triplicate and repeated at least three times in different days.

A mixed culture of bacteria was obtained from the mining effluent treatment by the enrichment technique. The BMV8 strain was isolated from this mixed culture and the taxonomic studies of this strain suggested that this bacteria may belong to the genus Pseudomonas. Identification to species level by numerical identification was often not possible. For the final identification of the strain, additional investigations such as $16 \mathrm{~S}$ rRNA analysis are needed. Bacteria isolated from industrial wastewaters by other authors were mainly assigned to the genera Acinetobacter, Alcaligenes, Bacillus, Citrobacter, Enterobacter, Escherichia, Klebsiella, Paracoccus, Pseudomonas, Thiobacillus $(5,7,8,11,16)$. The mixed culture (Fig.1 - a) and the BMV8 isolated strain (Fig.1 - b) were able to degrade thiocyanate heterotrophically using this compound as a nitrogen source. Most of the thiocyanate-utilizing microbes reported in the literature are autotrophs, and only few heterotrophs with ability to degrade thiocyanate have been described $(1,16,18,19)$. In the noninoculated control medium (M9), the levels of thiocyanate did not decrease during the incubation period. Thiocyanate utilization occurred mainly during the exponential phase of growth for both cultures. A similar result was previously reported for Arthrobacter species $(4,18)$. Unlike the mixed culture, BMV8 strain cultures showed the formation of $1.46 \mathrm{mM}$ ammonia after 36 hours of incubation. This amount decreased to $1.23 \mathrm{mM}$ within 48 hours (data not shown). However, no ammonia was found during thiocyanate degradation by the mixed culture, this may be due to rapid utilization of ammonia by bacteria metabolism during growth (14). Thiocyanate degradation lead to $\mathrm{pH}$ decrease and formation of carbonyl sulfide and ammonia that are toxic to organisms (11) and it is possible that these metabolites interfered the BMV-8 strain growth. The MICs determined for thiocyanate was represented in Fig.1- c. The mixed culture was able to tolerate thiocyanate concentrations of about 60 $\mathrm{mM}$, while BMV8 tolerated concentrations up to $45 \mathrm{mM}$. However, an initial inhibitory effect was observed to mixed and pure culture at $20 \mathrm{mM}$. The biomass decrease observed to mixed culture was smaller than BMV8, when thiocyanate concentration was increased suggesting that the higher tolerance of thiocyanate in the mixed culture may be attributable to a synergistic interaction between thiocyanatedegrading bacteria and other microorganisms. Thiocyanate removal (77\%) was observed only by the suspensions of cells of BMV8 strain previously grown in the presence of thiocyanate. However, the cells kept in ammonia removed only $10 \%$ of thiocyanate present in the medium (Fig.1-d). These results suggest that the enzyme(s) involved in thiocyanate degradation by the BMV8 strain is (are) inducible. Despite similar kinetics of thiocyanate degradation for the growing cells of the BMV8 strain and the mixed culture, thiocyanate degradation by the immobilized mixed culture (Fig.1-e) was shown to be greater than the capacity of degradation of the immobilized BMV8 strain (Fig.1- f). Both cultures were less efficient in the removal of thiocyanate when immobilized (Fig.1e and f). Many authors have reported differences in specific metabolic activity between free and immobilized microorganisms. The cause of these changes in cellular activity is still unclear and could be attributed to a modification of the physical and chemical environment of immobilized cells, or to an actual change in cellular physiology induced by immobilization (13).

The mixed culture of microorganisms and BMV8 were able to metabolize thiocyanate heterotrophically as a nitrogen source. Despite presenting similar kinetics of thiocyanate degradation in the suspended cultures, the mixed culture presented higher resistance against thiocyanate than the BMV8 strain. The best efficiency was achieved when the cells were immobilized. These advantages could be useful in bioprocesses for the treatment of thiocyanate-containing effluents.

\section{ACKNOWLEDGMENTS}

The authors are grateful to CNPq and FAPEMIG for financial support.

\section{RESUMO}

\section{Degradação de tiocianato por culturas puras e mixtas}

Uma cultura mixta e uma linhagem bacteriana pura foram isoladas de um bioreator para tratamento de tiocianato. As culturas removeram $5 \mathrm{mM}$ de tiocianato do meio em 36 horas. A cultura mixta foi capaz de tolerar concentrações superiores a $60 \mathrm{mM}$. A eficiência da degradação de tiocianato diminuiu quando as células foram imobilizadas.

Palavras chave: biodegradação, cianato, imobilização, microorganismos, tiocianato 

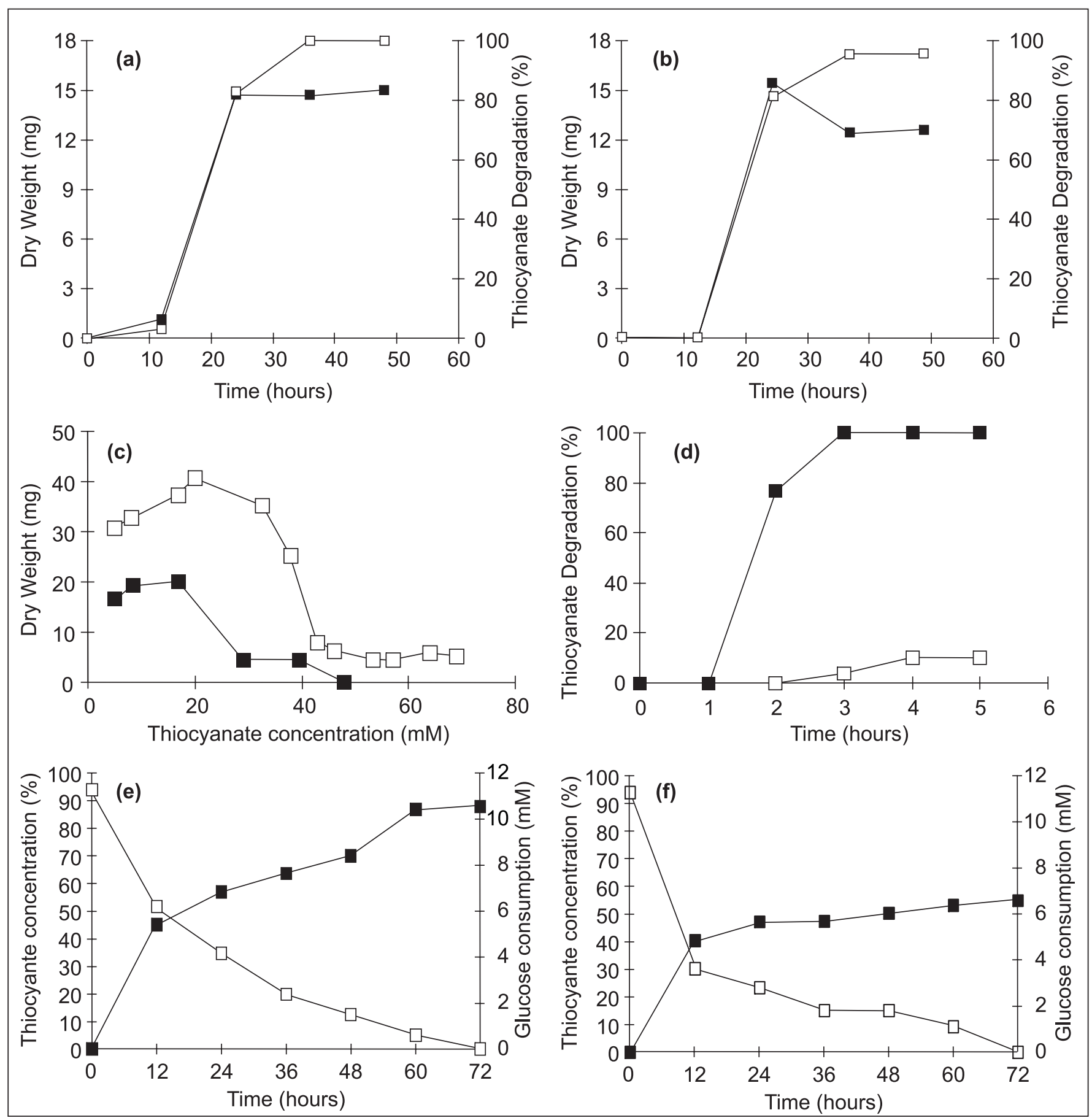

Figure 1. (a) - growth (- - ) and thiocyanate degradation ( $\square \square$ ) of the mixed culture on $5 \mathrm{mM}$ thiocyanate as a nitrogen source and $11 \mathrm{mM}$ glucose as a carbon and energy source; (b) - growth ( $\square-$ ) and thiocyanate degradation $(-\square-\square)$ of BMV8 on $5 \mathrm{mM}$ thiocyanate as a nitrogen source and $11 \mathrm{mM}$ glucose as a carbon and energy source; (c) MIC of the mixed culture ( $\square \square$ and of the BMV8 strain (- - ) ; (d) - thiocyanate degradation by a suspension of bacterial cells of the BMV8 strain previously grown in the presence of $5 \mathrm{mM}$ of thiocyanate ( $\square-$ ), or ammonia ( $\square-$ ); (e) - glucose as carbon and energy source (11 mM) $(\square-$ ) and thiocyanate degradation $(\square \square-$ ) by an immobilized mixed culture on $5 \mathrm{mM}$ thiocyanate as a nitrogen source; (f) glucose as carbon and energy source $(11 \mathrm{mM})(-\square-)$ and thiocyanate degradation $(-\square-)$ by the BMV8 strain immobilized on $5 \mathrm{mM}$ thiocyanate as nitrogen source. Representative data of one experiment. 


\section{REFERENCES}

1. Andreoni, V.; Ferrari, A.; Pagani, A.; Sorlini, C.; Tandoi, V.; Treccani, V. Thiocyanate degradation by denitrifying mixed cultures of bacteria. Anal. Microbiol., 38:193-200, 1988.

2. Bauchop, T.; Elsden, S.R. The growth of microorganisms in relation to energy supply. J. Gen. Microbiol., 23:457-469, 1960.

3. Beekhuis, H.A. Technology and biochemistry application. In: Newman, A.A. (ed.) Chemistry and biochemistry of thiocyanic acid and its derivatives. Academic Press, London, 1975, p.222-255.

4. Betts, P.M.; Rinder, D.F.; Fleeker, J.R. Thiocyanate utilization by an Arthrobacter. Can. J. Microbiol., 25:1277-1282, 1979.

5. Boucabeille, C.; Bories, A.; Olliver, P. Degradation of thiocyanate by a bacterial coculture. Biotechnol. Lett., 16:425-430, 1994.

6. Bozzi, A.; Guasaquillo, I.; Kiwi, J. Accelerated removal of cyanides from industrial effluents by supported $\mathrm{TiO}_{2}$ photo-catalysts. Appl. Cat. Env., 51:201-209, 2004.

7. Dubey, S.K.; Holmes, D.S. Biological cyanide destruction mediated by microorganisms. World J. Microb. Biot., 11:257-265, 1995.

8. Figueira, M.M.; Ciminelli, V.S.T.; Andrade, M.C.; Linardi, V.R. Cyanide degradation by an Escherichia coli strain. Can. J. Microbiol., 42:519-523, 1996

9. Fawcett, J.K.; Scott, J.E. A rapid and precise method for the determination of urea. J. Clin. Pathol., 13:156-159, 1960

10. Hung, C.H.; Pavlostathis, S.G. Aerobic biodegradation of thiocyanate. Wat. Res., 31:2761-2770, 1997.
11. Kim, S.; Katayama, Y. Effect of growth conditions on thiocyanate degradation and emission of carbonyl sulfide by Thiobacillus Thioparus TH115. Wat. Res., 34:2887-2894, 2000.

12. Miller, J.H. Experiments in Molecular Genetics, Cold Spring Harbor, New York, Cold Spring Harbor Laboratory, 1972, p.431-433.

13. Norton, S.; D'Amore, T. Physiological effects of yeast cell immobilization: applications for brewing. Enzyme Microb. Technol., 16:365-375, 1994.

14. Oliveira Dias, E.X. Thiocyanate degradation by a novel isolate. Kent, 1993, 251p. (Ph.D. Thesis. Faculty of Natural Sciences. University of Kent).

15. Somogyi, M. 1952. Notes on sugar determination. J. Biol. Chem., 195:19-23

16. Sorokin, D.Y.; Tourova, T.P.; Lysenko, A.M.; Kuenen, J.G. Microbial thiocyanate utilization under highly alkaline conditions. Appl. Env. Microb., 67:528-538, 2001.

17. Stafford, D.A.; Callely, A.G. The utilization of thiocyanate by heterotrophic bacterium. J. Gen. Microbiol., 55:285-289, 1969.

18. Stratford, J.; Dias, A.E.X.O.; Knowles, C.J. The utilization of thiocyanate as a nitrogen source by a heterotrophic bacterium: the degradative pathway involves formation of ammonia and tetrathionate. Microbiol., 140:2657-2662, 1994.

19. Youatt, J.B. Studies on the metabolism of Thiobacillus thiocyanoxidans. J. Gen. Microbiol., 11:139-49, 1954.

20. Zagury, G.J.; Oudjehani, K.; Deschênes, L. Characterization and availability of cyanide in solid mine tailings from gold extraction plants. Science Total Env., 320:211-224, 2004. 